\title{
The Role of Nursing in Scientific Investigation in Africa: A Retrospective Analysis
}

\author{
Grácio Maria $\mathrm{A}^{*}$ and Grácio António JS
}

Instituto de Higiene e Medicina Tropical, Universidade Nova de Lisboa, Rua da Junqueira, 100, 1349-008, Lisboa, Portugal

*Corresponding author: Grácio Maria A, Instituto de Higiene e Medicina Tropical, Universidade Nova de Lisboa, Rua da Junqueira 100, 1349-008, Lisboa, Portugal, Tel: +351213652600, E-mail: mameliahelm@ihmt.unl.pt

Citation: Grácio Maria A, Grácio António JS (2018) The Role of Nursing in Scientific Investigation in Africa: A Retrospective Analysis. J Nurs Patient Health Care 1(1): 102. doi: 10.15744/2767-9292.1.102

Received Date: July 16, 2018 Accepted Date: July 22, 2019 Published Date: July 24, 2019

\begin{abstract}
We think that there is a generalized opinion that nursing professionals have to possess a strong vocation for their profession, which can be compared with the priesthood. In Europe, during the Middle Ages, they were supported by the Catholic Church. It is believed that the first recorded aspects of nursing place the inception of the profession during the height of the Roman Empire, around 300 A.D. It was during this time that the Empire sought to place a hospital within every town under its rule. As such, there were male nurses during that time that assisted in in- patient medical care within the newly created hospital, alongside doctors [1]. In we have the History of Nursing of which we emphasized the role of nursing staff in the Crimean war in the 1850s, and in the current health system, nurses are one of the most trusted healthcare professionals with a significant role to play in the treatment and medical care of the sick [2]. Here we present our witness of the role that nursing played in the scientific investigation in Africa - Angola and Guinea Bissau, on malaria, plague, schistosomiasis and onchocerciasis.
\end{abstract}

Keywords: Nursing Africa Scientific Investigation

\section{Introduction}

Angola is an African country, situated on the western coast, which was a Portuguese province included in the group known as overseas provinces, until 11 November 1975, date of its independence. Several vectors and intermediate host - borne - diseases have occurred in Angola, between them malaria and schistosomiasis. The Instituto Nacional de Saúde Pública (National Institute of Public Health) where we have worked, has participated in control of several of these diseases. In the period between 1973 to 1975, we have participated principally in the fight against malaria and plague, which are here considered for our witness of the role of the nursing in the scientific investigation in Africa.

As to malaria, where the vectors are mosquitoes (Diptera: Insecta), it is endemic in Angola and for its control a project was started (projecto piloto de control da malária no distrito de Benguela) with activities divided into four zones: (i) witness zone, without intervention; (ii) zone with application of residual insecticide-DDT; (iii) zone with prophylaxis - daraclore every fifteen days; (iv) zone with application of residual insecticide -DDT and prophylaxis with daraclor, this is, association of the procedures of the zones (ii) and (iii) In that project the nursing staff have collaborated in: (i) epidemiological investigation; (ii) sampling of blood and its preparation for the search of Plasmodium spp; (iii) the activities for application of prophylaxis measures [3-6].

Concerning plague whose vectors are species of Siphonaptera (fleas), our studies were carried out in November 1973 and March 1974 in Benguela district, and in the outbreak of January to March 1975 in Monongue district [7,8]. In the first outbreak a total of 839 people were examined and close to 200 were hospitalized in the Bocoio hospital and Passe Sanitary Center, with the strong participation of nursing staff in all activities. In the second outbreak, owing to the political situation it isn't possible to examine and to treat patients in Menongue hospital. So, groups of nurses and other health staff, examined and treated the patients in their homes.

\section{Guinea Bissau}

Guinea Bissau, a country situated in West Africa on the Atlantic coast, was a Portuguese province, included in the group known as overseas provinces till august 1974, date of its independence. In the investigation in which we participated in that country, are 
the projects on schistosomiasis and the project on onchocerciasis.

\section{Schistosomiasis}

In the project TS2-025 - Schistosomiasis in Guinea Bissau, included in the Second Programme Science and Technology for Development - Health/ European Commission (1987-1991), the overall survey included 5,909 children in the 5-15 year age group, the nursing staff collaborated with us in the laboratory and field work. The collaboration included: (i) examination of urine samples for both schistosome eggs and haematuria; (ii) faecal examination for schistosomose eggs; (iii) treatment of all positive cases with 40mg Praziquantel/Kg, and in the preliminary study on morbidity in urogenital schistosomiasis $[9,10]$.

\section{Onchocerciasis}

In the project TS2-0060, Onchocerciasis in Guinea Bissau included in the same program of the project Schistosomiasis in Guinea Bissau, the nursing staff has collaborated with us: (i) in the execution and observation of the snips of the skin, a total of 2336, for detection of Onchocerca volvulus microfilariae; (ii) in treatment of infected individuals with Ivermectin- 200mg/kg [11,12].

In conclusion: with our witness on several scientific works developed by nursing staff in Africa - Angola and Guinea Bissau - we think that the importance of the nursing staff in the scientific investigation is evident.

\section{References}

1. The history of nursing.

2. Smith Y (2016) Roles of a Nurse: News-Medical.net, Manchester, UK.

3. Casaca VMR (1974) Instituto de Saúde Pública de Angola - Relatório Anual referente ao ano de 1973. Anais do Inst Hig Med trop 2: 582-585.

4. Casaca VMR (1975) Instituto de Saúde Pública de Angola - Relatório Anual referente ao ano de 1974. Anais do Inst Hig Med trop 2: 453-456.

5. Grácio AJS (1974) Relatório Anual referente a 1973 da Secção de Entomologia do Instituto de Saúde Pública de Angola. Anais do Inst Hig Med trop 2: 574.

6. Grácio AJS (1975) Relatório Anual referente a 1974 da Secção de Entomologia do Instituto de Saúde Pública de Angola. Anais do Ins Hig Med trop 2: $442-445$.

7. Grácio AJS, Grácio MA (2011) Plague in Angola. Acta Parasitol Port 18: 1-10.

8. Grácio AJS, Grácio MA (2017) Plague a millenary infectious disease reemerging in the XXI Century. BioMed Res Int 2017: 8 pages.

9. Grácio MA, Rollinson D, Costa C, Nhaque AT (1992) Intestinal Schistosomiasis: report of the first cases in Guinea Bissau. Trans Roy Soc of trop Med and Hyg 86: 183 .

10. Grácio MA, Nhaque AT, Rollinson D Schistosomiasis in Guinea Bissau. STD-2 Program Summaries of the final report: 239-247.

11. Grácio et al Onchocerciasis in Guinea Bissau. STD-2 Program Summaries of the final report: 571-574.

12. Grácio AJS, Shelley AJ, Raybould J, Gil Forte JA, Charalambous M et al. (2010) Eco-epidemiology of the onchocerciasis in Guinea Bissau (West Africa). Acta Parasitol Port 17: 23-39. 